DOI 10.46916/14022022-2-978-5-00174-472-6

\title{
ОРГАНИЗАЦИЯ СИСТЕМЫ УПРАВЛЕНИЯ ЗЕМЕЛЬНЫМИ РЕСУРСАМИ И РЕГУЛИРОВАНИЕ ЗЕМЕЛЬНЫХ ОТНОШЕНИЙ В КНР
}

\section{Попова Елена Викторовна}

К.Т.H.

Лю Цзинмин

магистр

ФГБОУ ВО «Дальневосточный государственный университет»

\begin{abstract}
Аннотация: детально рассмотрена структура управления земельными ресурсами КНР, которая функционально представляет собой четкую вертикаль, находящуюся в строгой зависимости от административного деления страны. Выявлены проблемы и недостатки в существующей системе управления земельными ресурсами. Установлено, что землеустроительные преобразования и решения земельно-имущественных проблем на перспективу должны осуществляться на сельских территориях в связи с тем, что рациональное и эффективное их использование послужит источником дальнейшего экономического роста КНР.
\end{abstract}

Ключевые слова: административно-территориальное деление, органы государственной власти, земельные отношения, земельный фонд.

\section{ORGANIZATION OF THE LAND MANAGEMENT SYSTEM AND REGULATION OF LAND RELATIONS IN CHINA}

\section{Popova Elena Viktorovna Liu Jingming}

\begin{abstract}
The structure of land management in China is considered in detail, which functionally represents a clear vertical, which is strictly dependent on the administrative division of the country. The problems and shortcomings in the existing land management system have been identified. It is established that and management transformations and solutions to land and property problems in the future should be
\end{abstract}


carried out in rural areas due to the fact that their rational and effective use will serve as a source of further economic growth of the China.

Key words: administrative-territorial division, state authorities, land relations, land fund.

Для более полного понимания организации системы управления земельными ресурсами в КНР и государственного регулирования земельных отношений необходимо четко представлять себе административное деление страны и структуру органов власти государства.

Учитывая значительную площадь Китайской Народной Республики, многочисленное и многонациональное население страны, сложившиеся естественно-исторические и социально-экономические условия, государство имеет многоуровневое административно-территориальное деление, закрепленное в Конституции:

1. Страна делится на провинции, автономные районы и города (муниципалитеты) центрального подчинения.

2. Провинции и автономные районы подразделяются на автономные префектуры, уезды, автономные уезды и города.

3. Уезды и автономные уезды подразделяются на волости, национальные волости и города уездного значения или поселки [1].

Характеристика провинций, городов центрального подчинения, автономных районов и особых административных районов дана в таблице 1 .

Таблица 1

Характеристика административно-территориального деления КНР

\begin{tabular}{|c|c|c|c|c|c|c|}
\hline Регионы & $\begin{array}{c}\text { Административ } \\
\text { ные центры }\end{array}$ & $\begin{array}{c}\text { Население, } \\
\text { млн. чел. }\end{array}$ & $\begin{array}{c}\text { Площадь, } \\
\text { млн. га }\end{array}$ & $\begin{array}{c}\text { Плотность, } \\
\text { чел./кв. км }\end{array}$ & $\begin{array}{c}\text { емлеобесп } \\
\text { ен/чест, },\end{array}$ & $\begin{array}{c}\text { Площадь } \\
\text { пахотных } \\
\text { земель, млн.га }\end{array}$ \\
\hline \multicolumn{7}{|c|}{ Города центрального подчинения } \\
\hline 1 & 2 & 3 & 4 & 5 & 6 & 7 \\
\hline Пекин & Пекин & 19,61 & 1,68 & 1166,85 & 0,086 & 0,344 \\
\hline Тяньцзинь & Тяньцинь & 12,94 & 1,19 & 1083,33 & 0,092 & 0,486 \\
\hline
\end{tabular}

Продолжение таблицы 1

\begin{tabular}{|c|c|c|c|c|c|c|}
\hline 1 & 2 & 3 & 4 & 5 & 6 & 7 \\
\hline Шанхай & Шанхай & 23,02 & 0,65 & 3541,41 & 0,028 & 0,315 \\
\hline Чунцин & Чунцин & 28,85 & 8,24 & 350,06 & 0,286 & 1,384 \\
\hline \multicolumn{2}{|l}{ Итого: } & $\mathbf{8 4 , 4 2}$ & $\mathbf{1 1 , 7 6}$ & $\mathbf{7 1 7 , 8 6}$ & $\mathbf{0 , 1 3 9}$ & $\mathbf{2 , 5 2 9}$ \\
\hline
\end{tabular}




\section{Продолжение таблицы 1}

\begin{tabular}{|c|c|c|c|c|c|c|}
\hline \multicolumn{7}{|c|}{ Провинции } \\
\hline Аньхой & Хэфэй & 59,50 & 14,05 & 423,49 & 0,236 & 5,9717 \\
\hline Ганьсу & Ланьчжоу & 25,58 & 45,92 & 55,69 & 1,795 & 5,0247 \\
\hline Гуандун & Гуанчжоу & 104,30 & 17,83 & 584,86 & 0,171 & 3,2722 \\
\hline Гуйчжоу & Гуйян & 34,75 & 17,50 & 198,58 & 0,504 & 4,9035 \\
\hline Ляонин & Шэньян & 43,75 & 14,75 & 296,68 & 0,337 & 8,201 \\
\hline Сычуань & Чэнду & 80,42 & 49,11 & 163,74 & 0,611 & 9,1691 \\
\hline Фуцзян & Фучжоу & 36,89 & 12,29 & 300,15 & 0,333 & 1,4347 \\
\hline Хайань & Хайкоу & 8,67 & 3,44 & 251,80 & 0,397 & 0,762 \\
\hline Хубэй & Ухань & 57,24 & 18,57 & 308,23 & 0,324 & 4,9495 \\
\hline Хунань & Чанша & 65,68 & 21,12 & 310,96 & 0,322 & 3,953 \\
\hline Хэбэй & Шицзячжуан & 71,85 & 18,72 & 383,75 & 0,261 & 6,8833 \\
\hline Хэйлунцзян & Харбин & 38,31 & 43,18 & 88,73 & 1,127 & 11,773 \\
\hline Хэнань & Чжэнчжоу & 94,02 & 16,63 & 565,35 & 0,177 & 8,1103 \\
\hline Цзилинь & Чанчунь & 27,46 & 19,10 & 143,75 & 0,696 & 5,5784 \\
\hline Цзянси & Наньчан & 44,57 & 17,10 & 260,57 & 0,384 & 2,9934 \\
\hline Цзянсу & Нанкин & 78,66 & 9,83 & 800,32 & 0,125 & 5,0617 \\
\hline Цинхай & Синин & 5,63 & 72,05 & 7,81 & 12,798 & 0,688 \\
\hline Чжэцзян & Ханчжоу & 54,43 & 10,61 & 513,08 & 0,195 & 2,1253 \\
\hline Шаньдун & Цзинань & 95,79 & 15,62 & 613,20 & 0,163 & 7,6893 \\
\hline Шаньси & Тайюань & 37,33 & 20,48 & 182,22 & 0,549 & 4,5886 \\
\hline Шэньси & Сиань & 35,71 & 14,97 & 238,55 & 0,419 & 5,1405 \\
\hline Юньнань & Куньмин & 45,97 & 38,86 & 118,28 & 0,845 & 6,4216 \\
\hline Итого: & & 1146,51 & 511,73 & 223,93 & 0,446 & 114,392 \\
\hline \multicolumn{7}{|c|}{ Автономные районы } \\
\hline $\begin{array}{c}\text { Внутренняя } \\
\text { Монголия - } \\
\text { АРBM }\end{array}$ & Хух-Хото & 24,71 & 118,11 & 20,92 & 4,780 & 8,201 \\
\hline
\end{tabular}




\begin{tabular}{|c|c|c|c|c|c|c|}
\hline \multicolumn{7}{|c|}{ Продолжение таблицы 1} \\
\hline 1 & 2 & 3 & 4 & 5 & 6 & 7 \\
\hline $\begin{array}{c}\text { Гуанси- } \\
\text { Чжуанский } \\
\text { автономный } \\
\text { район - ГЧАР }\end{array}$ & Наньнин & 46,03 & 23,50 & 195,86 & 0,511 & 4,4079 \\
\hline $\begin{array}{c}\text { Нинся- } \\
\text { Хуэнский } \\
\text { автономный } \\
\text { район - НХАР }\end{array}$ & Иньчуань & 6,30 & 5,22 & 120,74 & 0,829 & 1,2688 \\
\hline $\begin{array}{c}\text { Синьцзян- } \\
\text { Уйгурский } \\
\text { автономный } \\
\text { район - СУАР }\end{array}$ & Урумчи & 21,81 & 174,34 & 12,51 & 7,994 & 3,9857 \\
\hline $\begin{array}{c}\text { Тибетский } \\
\text { автономный } \\
\text { район - ТАР }\end{array}$ & Лхаса & 3,00 & 117,84 & 2,55 & 39,280 & 0,362 \\
\hline \multicolumn{2}{|l|}{ Итого: } & 101,85 & 439,01 & 23,20 & 4,310 & 18,2 \\
\hline \multicolumn{7}{|c|}{ Особые административные районы (ОАР) } \\
\hline $\begin{array}{c}\text { Сянчанский } \\
\text { ОАР-СОАР } \\
\text { (Гонконг) }\end{array}$ & $\begin{array}{l}\text { Гонконг } \\
\text { (Сянган) }\end{array}$ & 6,86 & 1,10 & 6268,81 & 0,160 & 0,0006 \\
\hline $\begin{array}{c}\text { Аомэнский } \\
\text { OАР33-АОАР } \\
\text { (Макао) }\end{array}$ & $\begin{array}{c}\text { Макао } \\
\text { (Аомынь) }\end{array}$ & 0,54 & 0,027 & 20044,44 & 0,050 & - \\
\hline Тайвань & Тайбей & 23,07 & 3,62 & 637,66 & 0,157 & 0,068 \\
\hline \multicolumn{2}{|l|}{ Итого: } & 30,47 & 4,747 & 641,47 & 0,156 & $\mathbf{0 , 0 7}$ \\
\hline \multicolumn{2}{|l|}{ Всего: } & 1363,25 & 967,25 & 140,98 & 0,71 & 135,191 \\
\hline
\end{tabular}

Анализируя таблицу 1, наглядно видно, что такие показатели как землеобеспеченность, га/чел $(0,028$ - 39,280), количество пахотных земель, млн.га $(0,0006-11,773)$ неоднородны по территории страны, что обуславливается особыми природными и демографическими условиями страны.

Административное деление страны определяет и структуру органов государственной законодательной, исполнительной и судебной власти.

Высшим органом государственной власти, осуществляющим законодательную деятельность в КНР, является Всекитайское собрание 
народных представителей (ВСНП). Постоянно действующим органом этого собрания служит Постоянный комитет (ПК ВСНП).

В регионах и на местах законодательную деятельность проводят местные собрания народных представителей (СНП), которые существуют на уровне провинций, включающим в себя собственно провинции, автономные районы и города центрального подчинения, а также на уровне округов и городов, уездов и волостей $[1,2]$.

В составе органов высшей государственной власти КНР имеется также Верховный народный суд КНР и Верховная народная прокуратура КНР.

Главным органом исполнительной власти на высшем уровне является Государственный совет (Госсовет) Китайской Народной Республики (Центральное Народное Правительство КНР). Государственный совет КНР формируется и подотчётен ВСНП.

На местах в стране действуют местные народные правительства, являющиеся государственными исполнительными органами власти в административно-территориальных образованиях различного уровня.

Собрания народных представителей и народные правительства учреждены в провинциях, городах центрального подчинения, уездах, городах (городских округах), муниципальных районах, волостях, национальных волостях и поселках. Порядок организации местных собраний народных представителей и местных народных правительств различных уровней определяется законом.

В автономных районах, автономных округах (префектурах) и автономных уездах учреждены органы самоуправления.

Современные земельные отношения и землеустройство в Китайской Народной Республике регулируются на основе земельного законодательства, четкой государственной земельной политики, которую проводит в жизнь земельная служба во главе с Министерством земельных и природных ресурсов КНР [2].

Министерство земельных и природных ресурсов КНР несет ответственность за планирование, управление, охрану и рациональное использование природных ресурсов, таких как: земельные и водные ресурсы (включая моря и океаническое побережье), а также за недра. Основные функции и полномочия Министерства представлены на рисунке 1. 


\begin{tabular}{|c|c|}
\hline \multirow{10}{*}{ 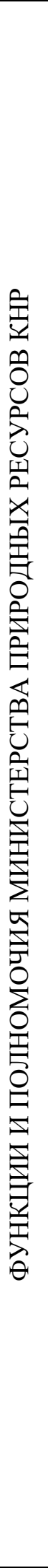 } & $\begin{array}{l}\text { Разрабатывать и обнародовать законы, постановления и другие нормативные правовые } \\
\text { акты, касающиеся управления земельными ресурсами, недрами (минеральными } \\
\text { ресурсами), водными ресурсами }\end{array}$ \\
\hline & $\begin{array}{l}\text { Определять политику в области управления, охраны и рационального использования } \\
\text { земли, недр и морских ресурсов, формулировать технические критерии (условия), } \\
\text { правила, стандарты и определять мероприятия, проводимые в отношении этих } \\
\text { ресурсов. }\end{array}$ \\
\hline & $\begin{array}{l}\text { Осуществлять контроль за исполнением земельного и природоресурсного } \\
\text { законодательства в рамках установленных компетенций различными Министерствами } \\
\text { и ведомствами и на различных уровнях административно-территориального } \\
\text { управления; реализовывать проекты землеустройства и природообустройства, } \\
\text { защищать законные права и интересы собственников и пользователей земельными, } \\
\text { водными и минеральными ресурсами; разрешать земельные и иные споры в сфере } \\
\text { землепользования и природопользования. }\end{array}$ \\
\hline & $\begin{array}{l}\text { Разрабатывать и претворять в жизнь политику и правила государства по охране } \\
\text { пахотных земель, особенно те из них, которые препятствуют изьятию пашни из } \\
\text { оборота и способствуют вовлечению в обработку новых земель; контролировать } \\
\text { целевое назначение и использование земель и, прежде всего, для нужд сельского } \\
\text { хозяйства; организовывать охрану ценных сельскохозяйственных земель; следить и } \\
\text { контролировать за площадями и состоянием неиспользуемых земель; способствовать } \\
\text { восстановлению и мелиорации сельскохозяйственных угодий. }\end{array}$ \\
\hline & $\begin{array}{l}\text { Определять правила ведения кадастра, организовывать землеустройство, проведение } \\
\text { кадастровых съемок, вести земельную статистику и динамический мониторинг земель; } \\
\text { осуществлять классификацию земель, регистрацию прав, вести учет сдельных участков } \\
\text { и других объектов }\end{array}$ \\
\hline & $\begin{array}{l}\text { Разрабатывать правила и осуществлять меры по установлению целевого назначения } \\
\text { земли, предоставлению земли в аренду, проведению оценки земель, по передаче и } \\
\text { трансформации прав на земельные участки; определять правила и порядок } \\
\text { использования земель, находящихся в государственной и коллективной собственности, } \\
\text { расположенных на территории городов и в сельской местности и др. }\end{array}$ \\
\hline & $\begin{array}{l}\text { Администрировать цены на землю: рыночную и нормативную (кадастровую), } \\
\text { проводить аккредитацию земельно-оценочных компаний (агентств), устанавливать } \\
\text { цены на земельные участки в зависимости от их целевого назначения, контролировать } \\
\text { решения Государственного совета в области землепользования и ресурсопользования. }\end{array}$ \\
\hline & $\begin{array}{l}\text { Организовывать и осуществлять надзор за недропользованием; выдавать лицензии на } \\
\text { использование и добычу полезных ископаемых; проводить контроль информации в } \\
\text { этой сфере, в особенности, со стороны иностранных инвесторов; создавать } \\
\text { геологические базы данных и управлять запасами полезных ископаемых; проводить } \\
\text { аккредитацию производственных организаций геологического и гео- } \\
\text { разведывательного профилей; осуществлять учет запасов полезных ископаемых и их } \\
\text { расходования. }\end{array}$ \\
\hline & $\begin{array}{l}\text { Вести мониторинг состояния минеральных ресурсов; осуществлять деятельность по } \\
\text { предотвращению стихийных бедствий и аварийных ситуаций при добыче полезных } \\
\text { ископаемых; проводить наблюдения и надзор исполнения законодательства в области } \\
\text { гидрогеологии, производства геологических работ и изысканий, эксплуатации } \\
\text { месторождений; осуществлять меры по рациональному использованию подземных вод; } \\
\text { поддерживать в надлежащем состоянии и охранять геологически важные территории. }\end{array}$ \\
\hline & $\begin{array}{l}\text { ести государственный реестр полезных ископаемых } \\
\text { спользованием природных ресурсов, находящихся в в }\end{array}$ \\
\hline
\end{tabular}

\section{Рис. 1. Функции и полномочия Министерства} земельных и природных ресурсов 


\section{СОВРЕМЕННЫЕ СОЦИАЛЬНО-ЭКОНОМИЧЕСКИЕ ПРОЦЕССЫ: ПРОБЛЕМЫ, ТЕНДЕНЦИИ, ПЕРСПЕКТИВЫ}

Землеустроительная документация включает: Генеральные планы использования земель (землеустройства), составляемые на различные территории и периоды времени: долгосрочный $(15-20$ лет), среднесрочный (5 лет) и годовой; проекты (планы) консолидации земель; проекты мелиорации, восстановления и рекультивации земель; проекты землеустройства, связанные с устойчивым развитием сельских территорий; проекты отвода земельных участков (предоставления и изъятия земель); проекты межевания земель с установлением (восстановлением) границ, определением площадей и местоположения земельных участков; планы планировки и застройки территорий; правила городского и сельскохозяйственного землепользования, определяющие виды и параметры разрешенного использования сельских территорий на основе их зонирования и классификации земель по целевому назначению и др.

Министерство земельных и природных ресурсов КНР оценивает структуру земельного фонда страны следующим образом (табл. 2)

Таблица 2

\section{Структура земельного фонда КНР}

\begin{tabular}{|c|c|c|}
\hline \multirow{2}{*}{ Виды земель } & \multicolumn{2}{|c|}{ Площадь } \\
\cline { 2 - 3 } & млн.га & $\%$ \\
\hline Обрабатываемая земля (пашня) & 124,74 & 12,7 \\
\hline Земля под садами & 11,81 & 1,2 \\
\hline Пастбища & 261,86 & 27,3 \\
\hline Лесная земля & 25,49 & 2,6 \\
\hline Земля жилого и промышленного назначения, включая шахты & 236,12 & 24,6 \\
\hline Земля транспорта и связи & 26,65 & 2,8 \\
\hline Земля водного хозяйства & 2,44 & 0,2 \\
\hline Прочая земля & 36,29 & 3,8 \\
\hline ИТОГО & 237,60 & 24,8 \\
\hline
\end{tabular}

Из таблицы 2 видно, что наиболее ценный вид земельных угодий пашня, занимает лишь 12,7\% общей площади государства. В состав пахотных земель входят: земли под сельскохозяйственными культурами, включая пахотные угодья; вновь и повторно распаханные целинные земли; выровненные и распланированные земли; земли под паром; морские и речные отмели с которых в среднем можно получать один урожай в год $[16,41,43]$. 
Реализуемый государством курс на ускоренную индустриализацию и урбанизацию за счет включения сельскохозяйственных земель в активный экономический оборот привели к следующим процессам в области землепользования и землеустройства:

увеличению числа и площадей отводов земель для нужд промышленности, транспорта, энергетики и иных целей обеспечивающих функционирование промышленных отраслей;

увеличение территорий городов, поселков в связи с миграционной составляющей, что влечет за собой предоставление новых участков и изъятие земель из сельскохозяйственного оборота;

сокращению площадей пахотных земель в результате проведения природоохранных мероприятий, восстановления на сельскохозяйственных землях уничтоженных лесов и объектов, обеспечивающих экологическую устойчивость;

выводу и ухудшению качества пахотных земель за счет природных катастроф, развития процессов водной эрозии и дефляции, засоления, заболачивания, загрязнения и других негативных деградационных процессов (табл. 3).

Таблица 3

Динамика площадей выбывшей из сельскохозяйственного оборота пашни

\begin{tabular}{|c|c|c|c|c|}
\hline Показатели & $1999-2000$ & $2001-2005$ & $2005-2019$ & Среднее \\
\hline $\begin{array}{c}\text { Отведено земель под строительство, } \\
\text { всего }\end{array}$ & 497,44 & 1314,35 & 1677,14 & 3488,93 \\
-в том числе пашни & 368,60 & 947,40 & 1115,75 & 2431,75 \\
\hline $\begin{array}{c}\text { Ежегодная площадь отвода земель в } \\
\text { среднем }\end{array}$ & 248,72 & 262,87 & 335,43 & 290,74 \\
-в том числе пашни & 184,30 & 189,48 & 223,15 & 202,65 \\
\hline $\begin{array}{c}\text { Общая площадь сокращения пашни } \\
\text { (строительство, стихийные }\end{array}$ & & & & \\
бедствия, экологические проблемы) & & & & \\
-всего за период & 2407,70 & 7616,70 & 2273,75 & 12298,15 \\
-в среднем за год & 1203,85 & 1523,34 & 454,75 & 1024,85 \\
\hline Общая площадь освоения земель в & & & & \\
пашню взамен утраченных & & & & \\
(освоение целины, структурное & & & & \\
упорядочение) & & & & \\
-всего за период & 1008,80 & 1603,30 & 1407,00 & 4019,10 \\
-в среднем за год & 504,40 & 320,66 & 281,40 & 334,92 \\
\hline
\end{tabular}


Из таблицы 3 видно, что наибольшее сокращение пахотных земель происходило в 2001-2005 гг., что и обусловило начало проведения жестких мер по охране этих угодий $[1,2]$.

В целях усиления контроля за состоянием и использованием сельскохозяйственных земель, которые к началу 2000-х годов начали резко сокращаться, в 2006 году при Министерстве земельных и природных ресурсов КНР были созданы специальные контрольно-надзорные органы, аналогично ранее существовавшей в Российской Федерации системе государственных инспекций по контролю за использованием и охраной земель соответствующими земельными инспекторами [2].

Были созданы также 9 региональных Бюро (управлений) по земельному надзору (контролю), находящихся в ведении Канцелярии Главного земельного инспектора (рис. 2).

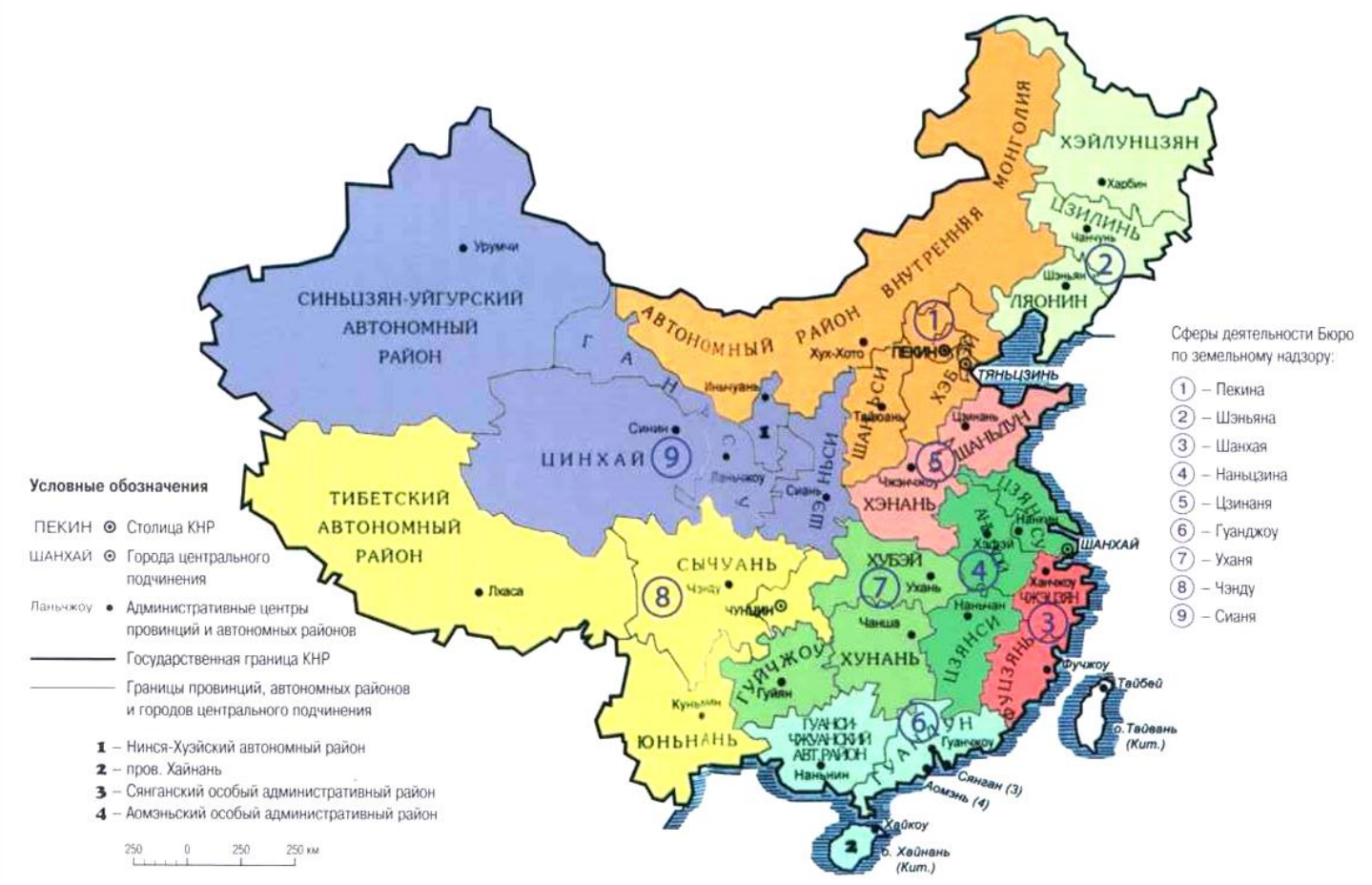

Рис. 2. Сферы деятельности Бюро по земельному надзору (контролю) за использованием земель в КНР

В их состав вошли:

Пекинское бюро, сферой деятельности которого являются города Пекин и Тяньцзинь, провинции Хэбэй и Шаньси, а также Автономный район Внутренний (АРВМ); 
Шеньянское бюро обеспечивает контроль земель в провинциях Ляонин, Цзилинь, Хэйлунцзян и г. Далянь;

Шанхайское бюро инспектирует земли в городах Шанхай, Сямэнь и Нинбо, в провинциях Чжэцзян и Фуцзянь;

Наньцзиньское бюро контролирует использование земель в провинциях Цзянсу, Аньхой, Цзянси;

Цзинаньское бюро осуществляет контрольно-надзорные функции в провинции Шаньдун, Хэнань и г. Циндао;

Гуанчжоуское бюро контролирует провинции Гуандун и Хайнань, Гуанси-Чжуарский автономный район (ГЧАР), а также г. Шэньчжэнь;

Уханьское бюро распространяет свои функции на провинции Хубэй, Хуань и Гуйчжоу;

Чэндусское бюро обеспечивает контроль в г. Чунцин, провинциях Сычуань, Юньнань и Тибетском автономном районе (ТАР);

Сианьское бюро инспектирует земли в провинциях Шэньси, Ганьсу, Цинхай, Нинся-Хуэйском автономном округе, а также территории производственно-строительных отрядов в Синьцзяне.

Финансирование кадастровой системы осуществляется из государственного бюджета КНР, а также из бюджетов местных властей. На поддержание кадастровой системы выделяются стабильные финансовые ресурсы.

Земельно-кадастровая система Китая содержит следующую информацию: публичную кадастровую карту; кадастровые планы территорий, дежурные кадастровые карты, кадастровые паспорта земельных участков; материалы, связанные с инфраструктурой пространственных данных; планы границ земельных участков в масштабах: от 1:100000 - в сельской местности и до 1:500 - в городах; данные учета земель и регистрации прав и выдачи документов на право землепользования; сведения о бальной оценке земель; кадастровые правила; порядок ведения земельного кадастра; сведения о подготовке и переподготовке кадров.

На Министерство земельных и природных ресурсов КНР возлагаются также полномочия в области регулирования земельной собственности и ее оценки, управления земельным рынком и землепользованием для строительных целей, проведение земельных изысканий и организации мониторинга земель, землеустройства на сельскохозяйственных территориях, планирования, развития и управления правами землепользования и др. 
Структура управления земельными ресурсами КНР функционально представляет собой четкую вертикаль, находящуюся в строгой зависимости от административного деления страны. При этом Китай создал свою уникальную систему государственного управления земельными и другими природными ресурсами. Благодаря чему удалось сохранить и приумножить земельно-ресурсный потенциал [2,3].

И, тем не менее, имеются проблемы, которые необходимо изучать и последовательно решать:

- многолетний экономический рост «любой ценой», экстенсивная модель развития, замедленное развитие экологической политики, несоблюдение основных законов в области охраны окружающей среды, коррупция, экологическая безграмотность населения привели к ухудшению экологической составляющей государства;

- наиболее серьезные проблемы земельной системы Китая сегодня уровневая структура имущественного права на землю, неравноправное положение системы коллективной собственности на землю по сравнению с системой государственной собственности во всех сферах: (в ограничении правомочий на землю, в отношении рынка земли; в части распределения дохода от капитализации земли; в наличии разных систем управления землей (в городе и деревне);

- китайская урбанизация - отчуждение сельских земель у крестьян с целью расширения границ городов - одновременно стала и драйвером экономического роста, и камнем преткновения в области земельно-правовых отношений;

- наличие большого количества законодательных актов, носящих временный характер, требует разработки концепции земельного законодательства с возможной разработкой Земельного кодекса КНР;

- отсутствие института кадастровой оценки существенно занижает налоговые поступления в бюджеты как федерального, так и муниципального уровней;

- отсутствие единого земельного кадастра (в связи с разделением на городской и сельский) не позволяют иметь абсолютно точный земельный баланс страны по площадям, формам собственности, видам угодий, категориям, что обуславливает совершенствование системы государственного учета земель на научном, методическом, технологическом и организационном уровнях; 
- необходимо осуществлять комплекс мероприятий по оценке земли как объекта недвижимости не только для целей налогообложения, но и в целях управления плодородием почв и охраны земли за счет выполнения качественной оценки земель;

- система землеустроительных мероприятий является основным эффективным инструментом для рационального использования земли, осуществляемая через планы и проекты землеустройства.

Bce землеустроительные преобразования и решения земельно-имущественных проблем на перспективу должны осуществляться на сельских территориях в связи с тем, что рациональное и эффективное их использование послужит источником дальнейшего экономического роста KHP [3].

Все эти мероприятия требуют постоянной актуализации данных кадастра и оценки земель, развития земельно-информационных систем, совершенствования технологий проведения земельно-кадастровых работ.

\section{Список литературы}

1. Конституция КНР 1982 года. С изменениями и дополнениями 2004 года. - URL: http://chinalawinfo.ru/all.

2. Волков С.Н. Земельная политика и управление земельными ресурсами в Китае/Учебно-научное издание. - Москва: ГУЗ, 2019. - 424 с.

3. Лю Цзяци, Попова Е.В. Развитие землевладения и землепользования КНР в ходе реформ / Строительство и природообустройство: сб. науч. тр. / М-во с.х. РФ ; Дальневост. гос. аграр. ун-т ;- Благовещенск: Изд-во Дальневост. гос. аграр. ун-та, 2019. - Вып. 4. - С. 81-88.

(C) Е.В. Попова, Лю Цзинмин, 2022 